\title{
HUBUNGAN TINGKAT PENGETAHUAN PENJUAL TERHADAP IDENTIFIKASI FORMALIN PADA IKAN ASIN DI PASAR TRADISIONAL KOTA DENPASAR TAHUN 2017
}

\section{(RELATIONSHIP BETWEEN THE LEVEL OF SELLER KNOWLEDGE TO IDENTIFICATION FORMALDEHYDE ON SALTED FISH IN DENPASAR TRADITIONAL MARKETS YEAR 2017)}

\author{
NI PUTU WIDAYANTI ${ }^{1}$, AYU SAKA LAKSMITA $\mathrm{W}^{1}$ \\ ${ }^{1}$ Institut Ilmu Kesehatan Medika Persada Bali, Jalan Tantular Barat No. 9 Renon, Denpasar, Bali
}

\begin{abstract}
Abstrak: Penelitian ini bertujuan untuk mengidentifikasi formalin pada ikan asin dan tingkat pengetahuan penjual ikan asin di Pasar Tradisional Kota Denpasar. Penelitian ini menggunakan 24 sampel yang diambil dari 6 pasar tradisional di Kota Denpasar. Identifikasi formalin pada ikan asin dilakukan dengan metode kalium permanganat $\left(\mathrm{KMnO}_{4}\right)$ sedangkan tingkat pengetahuan penjual diukur dengan kuesioner. Analisis data dilakukan secara univariat dan bivariat dengan uji chi-square $(\alpha=0,05)$. Sebanyak 7 dari 24 sampel ikan asin yang diuji positif mengandung formalin dan sebanyak 11 dari 24 responden yang memiliki tingkat pengetahuan rendah mengenai bahaya formalin. Terdapat hubungan yang signifikan antara tingkat pengetahuan penjual ( $\mathrm{p}$ $<0,05)$ terhadap hasil identifikasi formalin pada ikan asin di pasar Tradisional Kota Denpasar.
\end{abstract}

Kata Kunci: Formalin, Ikan Asin, Kalium Permanganat, Pasar Tradisional.

\begin{abstract}
The present study was conducted to identify formaldehyde on salted fish and the level of seller knowledge in Denpasar Traditional Markets. This research used 24 samples taken from six Denpasar Traditional Markets. Identification of formaldehyde in salted fish conducted using potassium permanganate (KMnO4) while the level of seller knowledge measured by a questionnaire. Data analysis was performed using univariate and bivariate with chi-square test $(\alpha=0.05)$. Seven from 24 samples tested positive were containing formaldehyde and eleven from 24 respondents who had a low level of knowledge about the dangers of formaldehyde. There is a significant relationship between the level of seller knowledge $(\mathrm{p}<0.05)$ to identification of formaldehyde on salted fish in Denpasar Traditional Markets.
\end{abstract}

Keyword: Formalin Salted fish, Potassium Permanganate, Traditional Market.

\section{PENDAHULUAN}

Ikan merupakan salah satu sumber protein hewani yang banyak dikonsumsi masyarakat, mudah didapat, dan harganya murah. Namun, ikan cepat mengalami proses pembusukan. Oleh sebab itu pengawetan ikan perlu diketahui semua lapisan masyarakat. Pengawetan ikan secara tradisional bertujuan untuk mengurangi kadar air dalam tubuh ikan, salah satu caranya adalah dengan pembuatan ikan asin (Hastuti, 2010). Penggaraman adalah teknik umum yang dimanfaatkan oleh masyarakat tradisional untuk mengawetkan ikan menjadi produk olahan ikan asin. Hampir 50\% hasil tangkapan ikan diolah secara tradisional dan ikan asin merupakan salah satu produk olahan ikan secara tradisional yang banyak dikonsumsi masyarakat (Wardhani dan Surahma, 2016). Pengolahan biasanya mengalami kesulitan dalam mengolah ikan asin pada musim hujan sehingga masyarakat biasanya memilih menggunakan BTP (Bahan Tambahan Pangan) untuk mengatasi hal tersebut (Mabonggi dkk., 2014).

Sosialisasi peraturan penggunaan food additives (bahan tambahan makanan) pada produk olahan makanan belum diketahui secara luas oleh masyarakat. Salah satu food additives yang sering dimanfaatkan masyarakat adalah bahan pengawet yang memiliki fungsi untuk meningkatkan daya simpan makanan. Pengolahan makanan yang ingin memperoleh keuntungan yang tinggi seringkali memilih formalin sebagai pengawet ikan asin bahkan dengan dosis yang melebihi ambang batas maksimal. Penggunaan formalin sebagai bahan pengawet makanan sangat membahayakan konsumen (Yuliarti, 2007). Formalin sering dipilih sebagai pengawet karena mudah didapat, harganya lebih murah, penggunaannya tidak sulit dan dapat

• email korespondensi: wida.yantisp@gmail.com 
menjaga tekstur dari ikan asin sehingga terlihat lebih menarik (Hastuti, 2010).

Denpasar memiliki banyak pasar tradisional yang menyediakan berbagai kebutuhan masyarakat terutama ikan asin. Ikan asin tidak hanya diminati oleh masyarakat sebagai makanan rumahan tetapi juga menjadi penunjang beberapa menu di tempat makan seperti restoran dan hotel. Dari hasil uji pendahuluan dengan metode survey, beberapa pasar tradisional di Denpasar menjual ikan asin dengan ciri-ciri fisik diantaranya memiliki warna terang, tidak dihinggapi lalat dan memiliki tekstur yang keras. Dengan demikian maka telah dilakukan penelitian mengenai identifikasi penggunaan formalin pada ikan asin dan tingkat pengetahuan penjual di Pasar Tradisional Kota Denpasar (Hastuti, 2010; Sinnggih, 2013; Mirna dkk, 2016).

\section{BAHAN DAN METODE}

Bahan. Bahan yang digunakan dalam penelitian ini adalah sampel ikan asin yang diperoleh dari Pasar Tradisional di Kota Denpasar, Kalium Permanganat $\left(\mathrm{KMnO}_{4}\right)$, dan akuades.

Metode. Penelitian ini dilakukan di beberapa Pasar Tradisional Kota Denpasar Provinsi Bali. Pengambilan sampel dilakukan di 6 pasar tradisional yang ada di Kota Denpasar yaitu pasar Kreneng (Denpasar Timur), pasar Sanglah (Denpasar Selatan), pasar Renon (Denpasar Selatan), pasar Abian Timbul (Denpasar Barat), pasar Kumbasari (Denpasar Barat), dan pasar Badung (Denpasar Utara). Waktu pelaksanaan dilakukan dari Bulan Desember 2016 - Februari 2017.

Cara pengumpulan data, yaitu dengan cara observasi dan kuesioner. Pengambilan sampel menggunakan metode survey dengan teknik purposive sampling yaitu pengambilan sampel yang didasarkan pada sampel yang memiliki ciriciri fisik diantaranya memiliki warna terang, tidak dihinggapi lalat, memiliki tekstur yang keras dan memiliki bau yang kurang khas. Metode survey merupakan penelitian yang mengambil sampel dari suatu populasi dengan menggunakan instrumen berupa kuesioner (Singarimbun dan Effendi, 1995).
Ikan asin yang diperoleh dari pasar tradisional Kota Denpasar, dipotong kecil-kecil kemudian dihaluskan dengan blender. Ikan asin yang sudah halus ditimbang sebanyak 2 gram, kemudian ditambahkan akuades sebanyak $30 \mathrm{ml}$. Campuran tersebut diaduk kemudian disaring hingga diperoleh filtratnya. Sebanyak $2 \mathrm{ml}$ filtrate dimasukkan ke dalam tabung reaksi, lalu ditambahkan 1 tetes larutan $\mathrm{KMnO}_{4}$. Campuran yang ada pada tabung reaksi digoyang-goyang hingga larutan $\mathrm{KMnO}_{4}$ da filtrat ikan asin tercampur. Keberadaan formalin ditunjukkan oleh hilangnya warna pink (merah muda) dari $\mathrm{KMnO}_{4}$. Pengulangan sampel dilakukan sebanyak 3 kali.

\section{HASIL DAN PEMBAHASAN}

Responden dalam penelitian ini sebanyak 24 orang dari 6 pasar tradisional di Kota Denpasar meliputi Pasar Kreneng, Pasar Sanglah, Pasar Renon, Pasar Abian Timbul, Pasar Kumbasari, dan Pasar Badung. Data responden yang dikumpulkan terdiri dari usia, jenis kelamin dan tingkat pendidikan. Data primer dikumpulkan dengan menggunakan kuesioner yang dilakukan dengan teknik wawancara serta observasi langsung.

Berdasarkan tabel 1, diketahui bahwa usia responden di Pasar Tradisional Kota Denpasar merupakan kelompok usia dewasa dengan persentase sebesar $100 \%$.

Tabel 1. Distribusi Usia Penjual Ikan Asin di Pasar Tradisional Kota Denpasar Tahun 2017

\begin{tabular}{lll}
\hline Usia* & Jumlah & Persentase \\
\hline Remaja & - & $0 \%$ \\
Dewasa & 24 & $100 \%$ \\
Lansia & - & $0 \%$ \\
\hline Total & 24 & $100 \%$ \\
\hline
\end{tabular}

Sebagian besar responden dari penelitian ini adalah perempuan dengan persentase $79,2 \%$ sedangkan laki-laki sebesar 20,8\% yang disajikan pada diagram 1. 


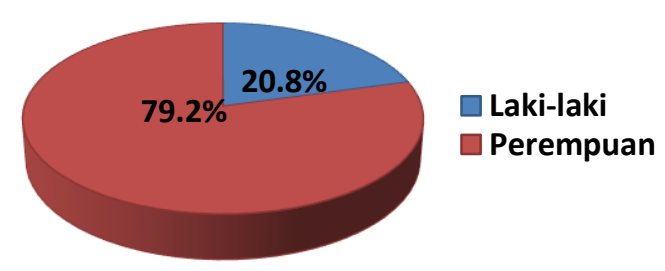

Diagram 1. Distribusi Jenis Kelamin Penjual Ikan Asin di Pasar Tradisional Kota Denpasar Tahun 2017

Tingkat pendidikan responden disajikan pada diagram 2. Berdasarkan diagram di bawah ini, tingkat pendidikan responden didominasi oleh tamatan SMP dengan persentase sebesar $37,5 \%$. Dalam penelitian ini, tidak terdapat responden yang memiliki tingkat pendidikan tamat Perguruan Tinggi.

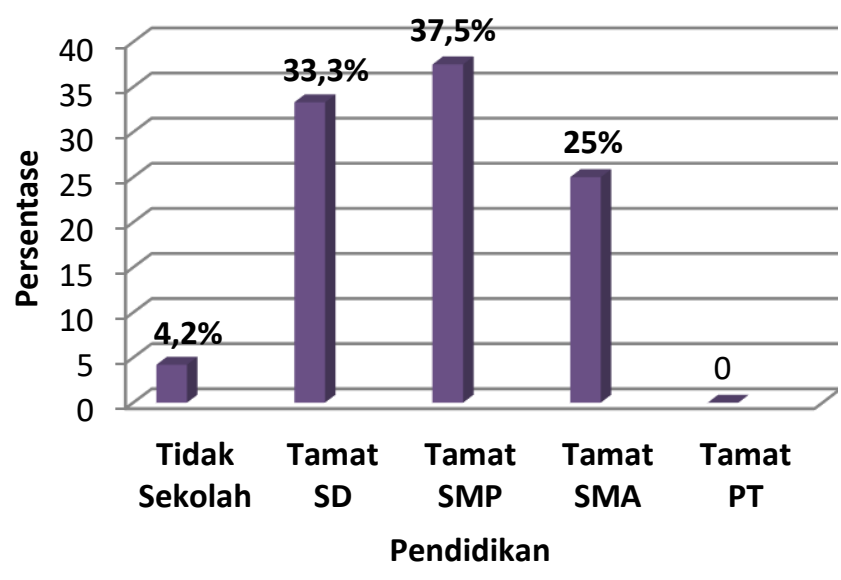

Diagram 2. Distribusi Tingkat Pendidikan Penjual

Ikan Asin di Pasar Tradisional Kota Denpasar Tahun 2017

Uji kandungan formalin pada ikan asin di Pasar tradisional Kota Denpasar dilakukan di laboratorium. Berdasarkan hasil uji laboratorium, dari 24 sampel ikan asin yang diteliti, terdapat 7 sampel $(29,2 \%)$ yang positif mengandung formalin (distribusi hasil uji kandungan formalin pada ikan asin disajikan pada tabel 2). Ciri fisik yang dapat diamati pada ikan asin yang mengandung formalin adalah tidak dihinggapi lalat, warnanya bersih/cerah dan tidak memiliki bau yang khas (Wardhani dan Surahma, 2016).

Pada penelitian ini sampel ikan asin diuji dengan reagen Kalium Permanganat (KMnO4) untuk mengetahui keberadaan formalin yang terdapat pada ikan asin. Sampel ikan asin yang positif mengandung formalin akan mengalami perubahan warna dari ungu menjadi bening. Formalin memiliki rumus kimia $\mathrm{HCHO}$ dan bersifat karsinogenik (menyebabkan kanker) serta bersifat mutagen (menyebabkan perubahan fungsi sel). Formalin merupakan racun bagi tubuh dan sangat berbahaya bagi kesehatan. Kandungan formalin yang tinggi dalam tubuh dapat menyebabkan kematian sel, iritasi lambung, alergi, kanker bahkan kematian akibat adanya kegagalan peredaran darah (Cahyadi, 2009).

Tabel 2. Distribusi Hasil Uji Kandungan Formalin pada Ikan Asin di Pasar Tradisional Kota Denpasar Tahun 2017

\begin{tabular}{lll}
\hline Hasil Uji Lab. & Jumlah & Persentase \\
\hline Positif & 7 & $29,2 \%$ \\
Negatif & 17 & $70,8 \%$ \\
\hline Total & 24 & $100 \%$ \\
\hline
\end{tabular}

Berdasarkan data primer yang diperoleh dalam penelitian ini, dapat diketahui bahwa sebanyak 13 responden $(54,2 \%)$ memiliki kategori pengetahuan tinggi mengenai ciri ikan asin berformalin dan dampak formalin bagi kesehatan. Sedangkan responden yang memiliki kategori pengetahuan rendah sebanyak 11 orang $(45,8 \%)$. Tingkat pengetahuan responden mengenai bahaya formalin dipengaruhi oleh tingkat pendidikan yang disandang oleh masing-masing responden. Responden yang hanya bersekolah sampai SD bahkan tidak bersekolah sangat minim pengetahuan tentang bahaya formalin bagi kesehatan. Distribusi tingkat pengetahuan penjual ikan asin terhadap bahaya formalin disajikan pada tabel 3 .

Tabel 3. Distribusi Tingkat Pengetahuan Penjual Ikan Asin terhadap Bahaya Formalin di Pasar Tradisional Kota Denpasar Tahun 2017

\begin{tabular}{lll}
\hline Pengetahuan & Jumlah & Persentase \\
\hline Rendah & 11 & $45,8 \%$ \\
Tinggi & 13 & $54,2 \%$ \\
\hline Total & 24 & $100 \%$ \\
\hline
\end{tabular}


Responden yang memiliki tingkat pengetahuan rendah dengan hasil uji positif formalin pada ikan asin yaitu sebesar 25\% sedangkan hasil uji negatif formalin sebesar 20,8\%. Responden yang memiliki tingkat pengetahuan tinggi dengan hasil uji positif formalin pada ikan asin yaitu sebesar 4,2\% sedangkan hasil uji negatif formalin sebesar 92,3\%. Distribusi hubungan tingkat pengetahuan responden terhadap identifikasi formalin pada ikan asin disajikan pada tabel 4 .

Tabel 4. Distribusi Hubungan Tingkat Pengetahuan Responden terhadap Identifikasi Formalin pada Ikan Asin di Pasar Tradisional Kota Denpasar Tahun 2017

\begin{tabular}{cccccccc}
\hline $\begin{array}{c}\text { Variabel } \\
\text { (Pengeta } \\
\text { huan) }\end{array}$ & \multicolumn{2}{c}{ Positif } & \multicolumn{2}{c}{ Negatif } & \multicolumn{2}{c}{ Total } & \\
\hline Rendah & 6 & 25 & 5 & 20,8 & 11 & 45,8 & \\
& & & & & & & 0,012 \\
Tinggi & 1 & 4,2 & 12 & 92,3 & 13 & 54,2 & \\
\hline Jumlah & 7 & 29,2 & 17 & 70,8 & 24 & 100 & \\
\hline
\end{tabular}

Berdasarkan analisis bivariat yang disajikan pada tabel $2 \times 2$, diketahui bahwa terdapat hubungan yang signifikan antara tingkat pengetahuan penjual $(\mathrm{p}<0,05)$ terhadap hasil identifikasi formalin pada ikan asin di pasar tradisional Kota Denpasar.

\section{SIMPULAN}

Berdasarkan hasil uji laboratorium dengan reagen Kalium Permanganat $(\mathrm{KMnO} 4)$, terdapat 7 sampel $(29,2 \%)$ yang positif mengandung formalin dari 24 total sampel ikan asin yang diidentifikasi dari Pasar Tradisional Kota Denpasar. Responden yang memiliki tingkat pengetahuan rendah dengan hasil uji positif formalin pada ikan asin yaitu sebesar 25\% sedangkan hasil uji negatif formalin sebesar $20,8 \%$. Responden yang memiliki tingkat pengetahuan tinggi dengan hasil uji positif formalin pada ikan asin yaitu sebesar 4,2\% sedangkan hasil uji negatif formalin sebesar 92,3\%. Dari hasil uji bivariat dengan chi square, terdapat hubungan yang signifikan antara tingkat pengetahuan penjual $(\mathrm{p}<0,05)$ terhadap hasil identifikasi formalin pada ikan asin di pasar tradisional Kota Denpasar.

\section{DAFTAR PUSTAKA}

Cahyadi, W., 2009, Analisis Aspek dan Kesehatan Bahan Tambahan Pangan, 2nd ed, Bumi Aksara, Jakarta.

Hastuti, S., 2010, Analisis Kualitatif dan Kuantitatif Formaldehid pada Ikan Asin di Madura, AGROINTEK, 4(2), pp.132-37.

Mabonggi, L., Naiu, A.S. \& Mile, L., 2014, Uji Formalin pada Ikan Teri Asin Kering di Gorontalo. Jurnal Ilmiah Perikanan dan Kelautan, 11(1), pp.1-3.

Mirna, La, K \& Nur, A., 2016, Analisis Formalin pada Ikan Asin di beberapa Pasar Tradisional Kota Kendari. J. Sains dan Teknologi Pangan, 1(1), pp.1-3.

Singarimbun, M. dan Effendi, S., 1995, Metode Penelitian Survei, PT Pustaka LP3ES Indonesia, Jakarta.

Sinnggih, H., 2013, Uji Kandungan Formalin Pada Ikan Asin Menggunakan Sensor Warna Dengan Bantuan FMR, Jurnal ELTEK, 11(01).

Wardhani, R.I. \& Surahma, A.M., 2016, Identifikasi Formalin pada Ikan Asin yang dijual di Kawasan Pantai Teluk Penyu Kabuopaten Cilacap. Kesehatan Masyarakat, 10(1), pp.5-24.

Yuliarti, N., 2007, Awas Bahaya di Balik Lezatnya Makanan, Andi, Yogyakarta. 